NOTE

\title{
Tidal migration of nematodes on an estuarine tidal flat (the Molenplaat, Schelde Estuary, SW Netherlands)
}

\author{
M. Steyaert ${ }^{1, *}$, P. M. J. Herman ${ }^{2}$, T. Moens ${ }^{1}$, J. Widdows $^{3}$, M. Vincx ${ }^{1}$ \\ ${ }^{1}$ Ghent University, Biology Department, Marine Biology Section, K.L. Ledeganckstraat 35, 9000 Gent, Belgium \\ ${ }^{2}$ Netherlands Institute for Ecology, Centre for Estuarine and Coastal Ecology, Korringaweg 7, PO Box 140, 4400 AC Yerseke, The Netherlands \\ ${ }^{3}$ Plymouth Marine Laboratory, Prospect Place, The Hoe, Plymouth PL1 3DH, United Kingdom
}

\begin{abstract}
The vertical distribution patterns of the nematode community and of the 10 most dominant nematode species on an intertidal flat in the Schelde Estuary (the Molenplaat, The Netherlands) are described at specific time intervals over a tidal cycle. The observed distribution profiles indicate that vertical migrations occur and are species-specific. The predatory Enoploides longispiculosus and the deposit-feeding Daptonema normandicum migrated upwards at incoming tide and downwards when the flat became exposed, while another deposit feeder, Daptonema setosum, did the opposite. Several abiotic and biotic factors may contribute to the observed patterns. Hydrodynamics, pore water drainage and episodic steep increases in temperature upon low tide exposure as well as vertical movements of prey organisms may have been of particular relevance at the time and site of sampling. However, the impact of each of these factors needs further investigation. The present study corroborates the dynamic nature of vertical distribution profiles of nematodes in intertidal sediments, highlighting the importance of sampling time with respect to the tide, as well as a species approach.
\end{abstract}

KEY WORDS: Meiobenthos - Nematodes - Westerschelde Tidal flat $\cdot$ Migration $\cdot$ Tidal cycle

Resale or republication not permitted without written consent of the publisher

Meiobenthos often shows an aggregated vertical distribution within the sediment. The causes of this patchiness are often complex. In intertidal habitats, the tides can be expected to have an important dynamic impact on the chemical and physical environment of organisms living in the sediment. Factors such as temperature, wave action, currents, organic input, percolation of interstitial water, light intensity, compaction of the sediment and others will change periodically with the tidal cycle. This fluctuating environment provides a challenge to benthic organisms and forces them to adapt to an unstable environment or to migrate to deeper sediment layers.

\footnotetext{
*E-mail: maaike.steyaert@rug.ac.be
}

Earlier research has demonstrated tidal migrations for nematodes and linked these to a variety of both biotic and abiotic environmental factors (RenaudDebyser 1963, Boaden \& Platt 1971, Palmer \& Gust 1985, Palmer 1986, 1988, Fegley 1987). These studies mainly concentrated on the total nematode community, however. There are few studies at the species level (Rieger \& Ott 1971).

Here we investigate tidal migration of nematodes on the species as well as on the community level, and test whether the community level approach masks speciesspecific patterns. This study was carried out within the frame of a multidisciplinary research project, ECOFLAT, which aims to study the ecometabolism of the Molenplaat, SW Netherlands. On this tidal flat, the spatial structure of nematode communities has been studied intensively in a previous phase of the project.

Study site and methods. The Molenplaat is a tidal flat in the polyhaline reach of the Schelde estuary, with a surface area of approximately $1.5 \mathrm{~km}^{2}$. Considerable heterogeneity in sediment characteristics is found on this tidal flat, with sediments ranging from fine sand with a high silt fraction to medium sand without silt. Most of the tidal flat is located between -1 and $+1 \mathrm{~m}$ relative to mean tidal level (approximately $2.75 \mathrm{~m}$ to mean low water) and is subjected to a tidal amplitude of about $5 \mathrm{~m}$ (Middelburg et al. 2000). Exposure time is about $7 \mathrm{~h}$ each tidal cycle (Herman et al. 2000). Sediments collected for the present study mainly consist of fine sand (median grain size $172 \mu \mathrm{m}$-Malvern particle analyser), with only a minor silt fraction $(<5 \%)$ (J. J. Middelburg pers. comm.). The site is characterised by a relatively high bottom shear stress (1.15 Pa) (MP 4 in Herman et al. 2000), and was selected because tidal migration of nematodes could be expected to be more pronounced in hydrodynamically impacted sediments. 


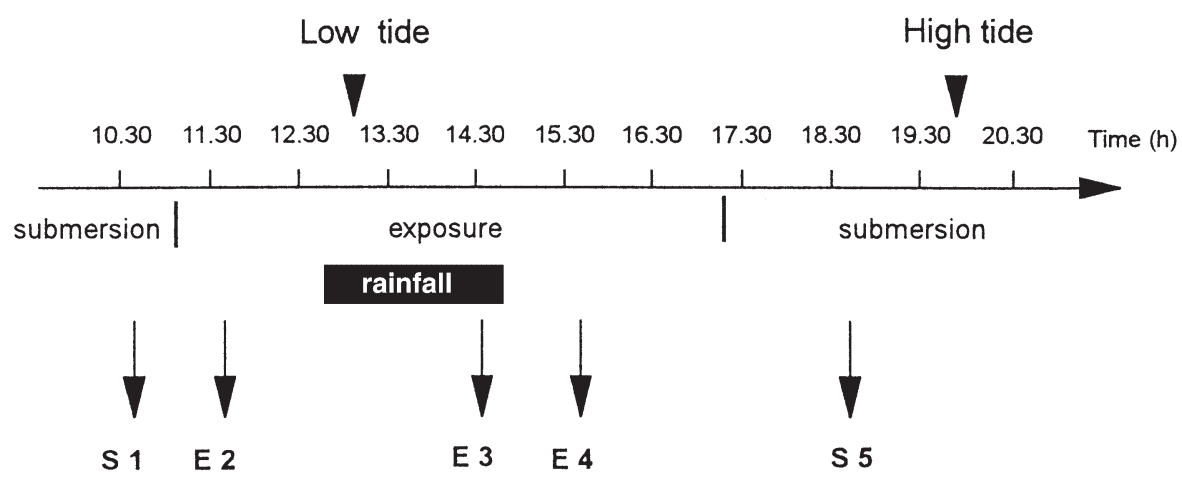

Fig. 1. Sampling time of the 5 events (S1, E2, E3, E4 and S5)

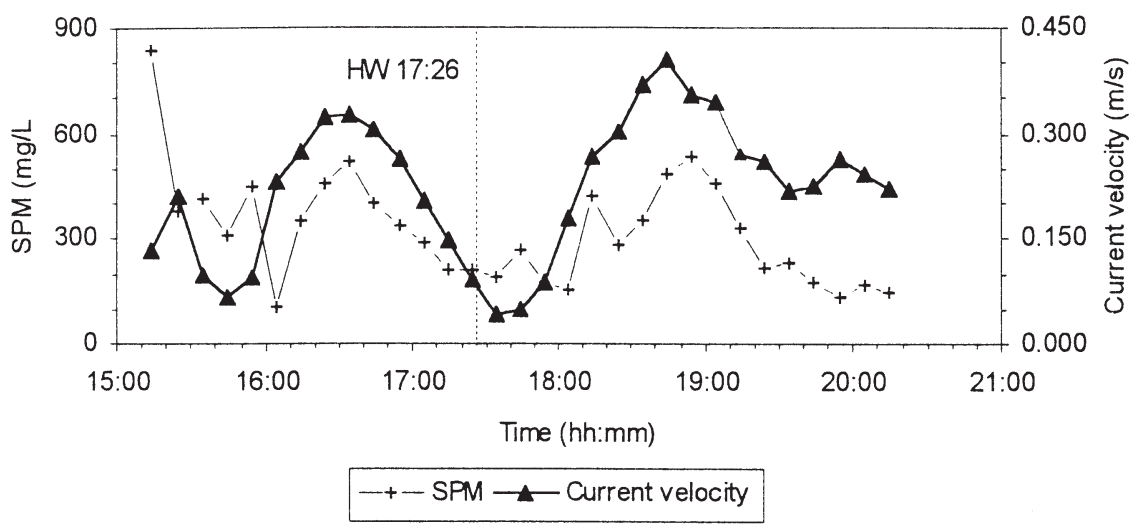

Fig. 2. Suspended particular matter (SPM) and current velocity during submersion (7 June 1997)

Sampling strategy: On 11 June 1997, triplicate $3.6 \mathrm{~cm}$ i.d. perspex cores were taken at 5 different sampling events (Fig. 1) during daytime. The first sampling (event S1) was performed at the end of the ebbing tide (remaining water cover of about $20 \mathrm{~cm}$ ). Sampling events 2, 3 and 4 (respectively events E2, E3, E4) took place at different moments during low-tide exposure. The last series of samples (event S5) was collected $70 \mathrm{~min}$ before high tide (1.5 m water cover). Measurements on 7 June 1997 at the same site indicated that current velocities were highest 70 min before and after high tide (33 and $40 \mathrm{~cm} \mathrm{~s}^{-1}$ respectively), and lowest during high tide (Fig. 2). Heavy rainfall occurred before E3 between 12:40 and 13:10 h.

All cores were carefully subdivided into depth slices $(0-0.5,0.5-1,1-1.5,1.5-2,2-3,3-4 \mathrm{~cm})$ in order to minimise disturbance. Samples were further treated as described in Steyaert et al. (1999).

The temperature at the sediment surface measured 25.8 and $30.7^{\circ} \mathrm{C}$, respectively 1 and $4 \mathrm{~h}$ after exposure. At a depth of $2 \mathrm{~cm}$, the corresponding values were 22.9 and $28.9^{\circ} \mathrm{C}$, and at a depth of $3.5 \mathrm{~cm}$ the temperature never exceeded $26.9^{\circ} \mathrm{C}$. Water temperature on the day of sampling averaged $17.3^{\circ} \mathrm{C}(0.5 \mathrm{~m}$ depth $)$.
Statistical analysis: Univariate 2-way analysis of variance (ANOVA) was used to test for differences of total nematode densities, as well as of the densities of the 10 most dominant nematode species, with time, depth and time $\times$ depth. A 'split-plot' design was constructed with replicates nested within 'time', however, not within 'depth'. All data were $\log (x+1)$ transformed prior to analysis. Subsequently, a multivariate 2-way ANOVA was performed in order to test if the relative species composition of the nematode community changed as a function of time, depth and time $\times$ depth. This MANOVA test, using Wilkinson's lambda, was based on the same design as for the univariate ANOVA.

Results. The analysis is restricted to the total nematode community and to the following 10 most abundant species: Ascolaimus elongatus (1.3\%), Cyatholaimus gracilis $(1.9 \%)$, Daptonema normandicum $(15.3 \%), D$. setosum (3.6\%), Enoploides longispiculosus $(40.2 \%)$, Hypodontolaimus trichophora $(4.2 \%)$, Microlaimus marinus $(2.2 \%)$, Theristus blandicor $(10.2 \%), T$. pertenuis $(1.4 \%)$ and Viscosia viscosa $(9.4 \%)$. For 2 of these, $C$. gracilis and $M$. marinus, significant differences in total, depth-integrated density were found be- 
Table 1. Univariate and multivariate ANOVA tests

\begin{tabular}{|c|c|c|c|c|c|c|c|c|c|}
\hline \multirow[t]{2}{*}{ Univariate tests } & \multicolumn{3}{|c|}{ Time } & \multicolumn{3}{|c|}{ Depth } & \multicolumn{3}{|c|}{ Time $\times$ Depth } \\
\hline & df & $F$ & $\mathrm{p}$ & df & $F$ & $\mathrm{p}$ & $\mathrm{df}$ & $F$ & $\mathrm{p}$ \\
\hline Nematode community & 4 & 0.998 & 0.452 & 5 & 15.019 & $<0.001$ & 20 & 0.875 & 0.616 \\
\hline Ascolaimus elongatus & 4 & 1.342 & 0.320 & 5 & 8.471 & $<0.001$ & 20 & 2.093 & 0.018 \\
\hline Cyatholaimus gracilis & 4 & 0.960 & 0.470 & 5 & 8.068 & $<0.001$ & 20 & 0.999 & 0.480 \\
\hline Daptonema normandicum & 4 & 2.063 & 0.161 & 5 & 46.475 & $<0.001$ & 20 & 1.232 & 0.269 \\
\hline D. setosum & 4 & 0.755 & 0.577 & 5 & 47.695 & $<0.001$ & 20 & 3.234 & 0.000 \\
\hline Enoploides longispiculosus & 4 & 1.628 & 0.242 & 5 & 79.455 & $<0.001$ & 20 & 1.971 & 0.027 \\
\hline Hypodontolaimus trichophora & 4 & 3.222 & 0.061 & 5 & 15.211 & $<0.001$ & 20 & 2.490 & 0.005 \\
\hline Theristus blandicor & 4 & 2.024 & 0.167 & 5 & 33.721 & $<0.001$ & 20 & 2.443 & 0.005 \\
\hline Microlaimus marinus & 4 & 3.802 & 0.039 & 5 & 25.520 & $<0.001$ & 20 & 1.588 & 0.094 \\
\hline T. pertenuis & 4 & 6.025 & 0.010 & 5 & 20.974 & $<0.001$ & 20 & 3.943 & 0.000 \\
\hline Viscosia viscosa & 4 & 0.372 & 0.824 & 5 & 16.942 & $<0.001$ & 20 & 2.324 & 0.008 \\
\hline Multivariate test & 40.5 & 3.339 & 0.074 & 50.19 & 10.574 & $<0.001$ & 200.39 & 2.163 & 0.001 \\
\hline
\end{tabular}

tween sampling events; their density was higher during tidal flat exposure (Fig. 3). This probably reflects upwards migration of nematodes from below $4 \mathrm{~cm}$.

During submersion (S1 and S5), total nematodes reached a maximal density in the surface layer of the sediment, with the depth profile of S5 being less pronounced. In contrast, upon low tide exposure, the highest fraction was recorded in the 0.5 to $1 \mathrm{~cm}$ depth horizon. An exception to this rule was E3, when the total nematode depth distribution strongly resembled that during submersion. The abundance of total nematode community (Table 1) changed significantly in depth, while no significant variation in time was found. Neither was the interaction between time and depth significant. Hence, the depth profile of total nematode density did not fluctuate significantly with time.

Similar vertical distribution trends as for total nematodes were observed for the predacious Enoploides longispiculosus. This nematode showed a preference for the upper sediment layers during submersion, while during exposure it was most abundant in the subsurface layers (Fig. 3). Note that there are minor differences between the 2 submerged sampling events. During S5 this species showed a slight subsurface $(0.5$ to $1 \mathrm{~cm})$ peak. However, it was far less pronounced than in the foregoing exposed situation, E4. Daptonema normandicum, a deposit feeder, also reached a maximal abundance in the surface layer during submersion, while showing a downward shift during exposure (Fig. 3). Interestingly, its congener $D$. setosum presented a similar vertical profile during submersion. However, this species' highest abundance was recorded in the upper layers during low tide exposure (Fig. 3). Here again, the depth profiles of both $D$. normandicum and $D$. setosum were less pronounced during high tide (S5) compared to the ebbing situation (S1). None of the other species showed a consistent migration trend as a function of the tide.
Univariate tests on the distribution of the individual nematode species revealed that, except for Microlaimus marinus and Theristus pertenuis, the abundances were not significantly influenced by time. As for the total nematode community, the distribution profiles of all species altered significantly with depth. In contrast to total nematodes, the time $\times$ depth interaction was significant for 7 out of 10 species: Ascolaimus elongatus, Daptonema setosum, Enoploides longispiculosus, Hypodontolaimus trichophora, T. blandicor, T. pertenuis and Viscosia viscosa.

Multivariate analysis showed that nematode species composition was not significantly affected by time. Composition, however, did exhibit a significant effect of depth and a significant effect of the interaction term time $\times$ depth. The combination of univariate and multivariate analyses demonstrate that, while total nematode density does not reveal a tidal signal, tidal migrations of nematodes exist and are significant at the community level, i.e. the structure of the nematode community varies with depth over a tidal cycle.

Discussion. The results of this study do not corroborate the general hypothesis that nematodes migrate deeper into the sediment as the tide comes in: submersion of the sampling site provoked upward movement of Daptonema normandicum, Enoploides longispiculosus and total nematodes in general. In contrast, the behaviour of $D$. setosum resembles that of Microlaimus marinus as noted by Rieger \& Ott (1971): a downward migration during submersion.

Several abiotic and biotic factors as well as their combinations may explain the observed vertical displacements. Increased current velocities are thought to be of prime importance in inducing downward movement as an avoidance strategy against being eroded (Palmer \& Gust 1985, Palmer 1986, Fegley 1987). In this respect, Boaden \& Platt (1971) found that nematodes generally occurred deeper in the sediments dur- 


\section{$\begin{array}{lllll}\text { S1 } & E 2 & \text { E3 } & \text { E4 } & \text { S5 }\end{array}$}

\section{Ascolaimus elongatus}
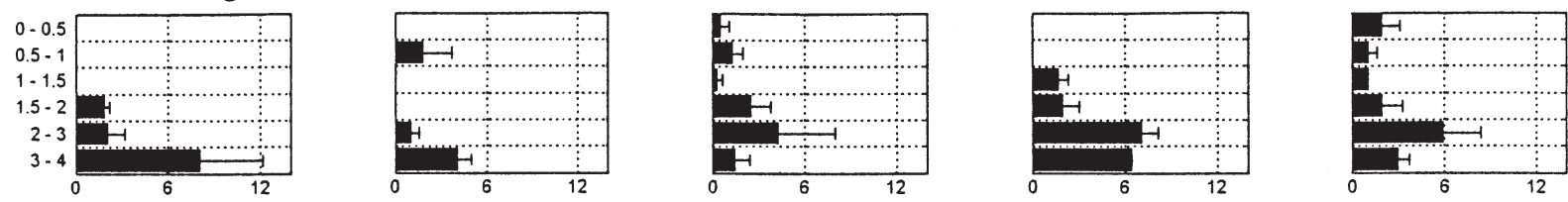

\section{Cyatholaimus gracilis}
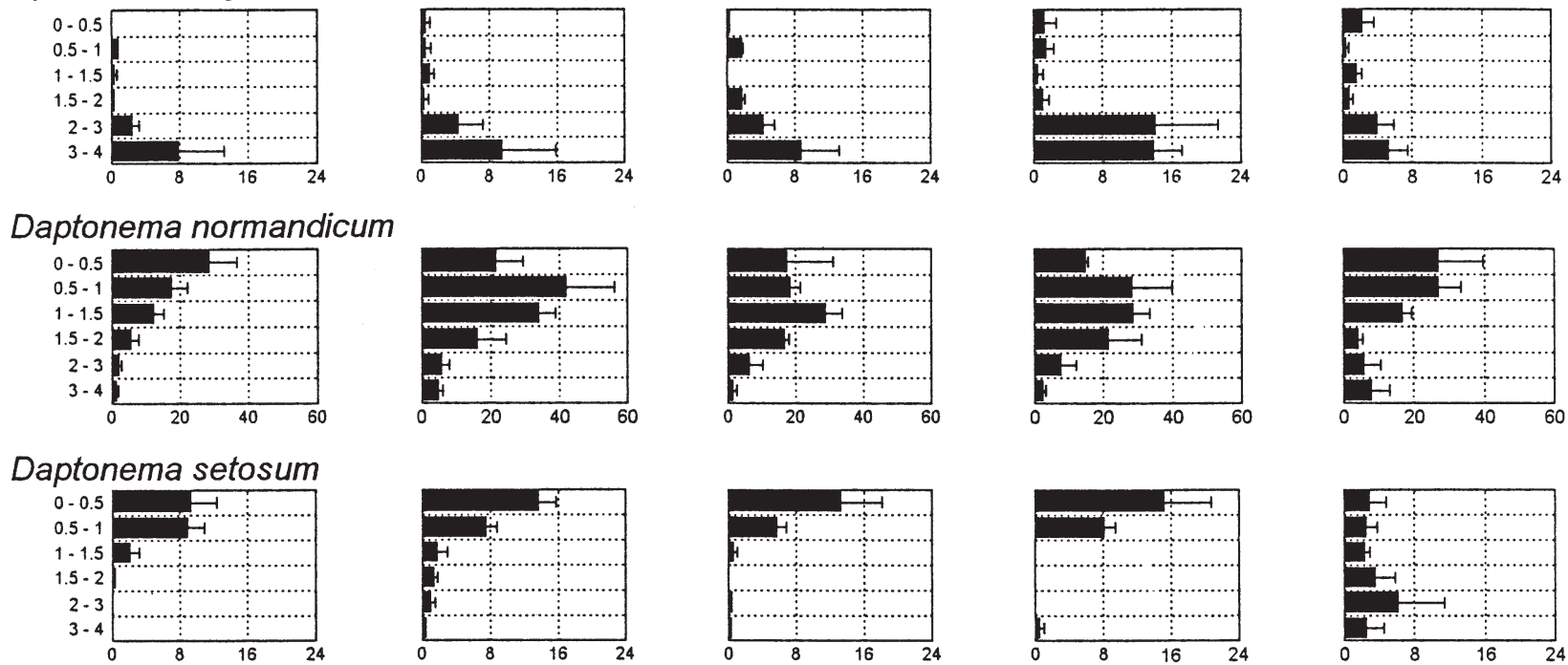

\section{Enoploides longispiculosus}
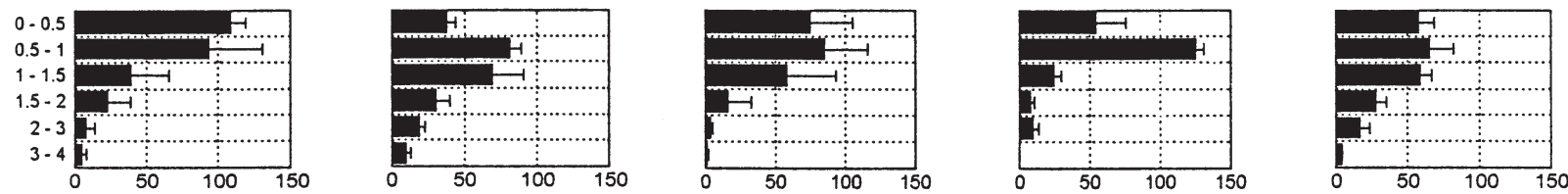

\section{Hypodontolaimus trichophora}
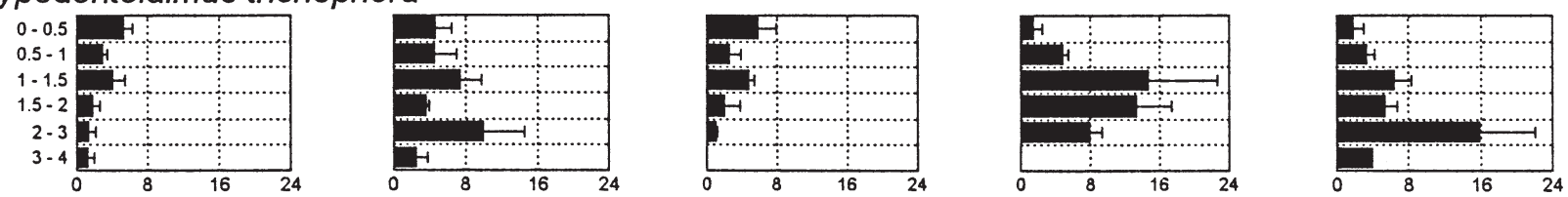

\section{Microlaimus marinus}
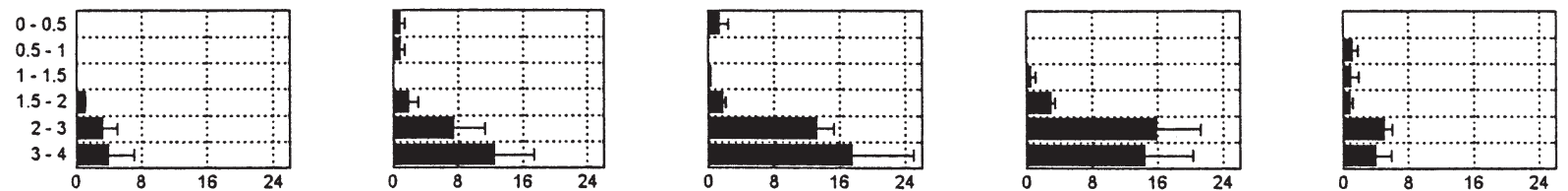

\section{Theristus blandicor}
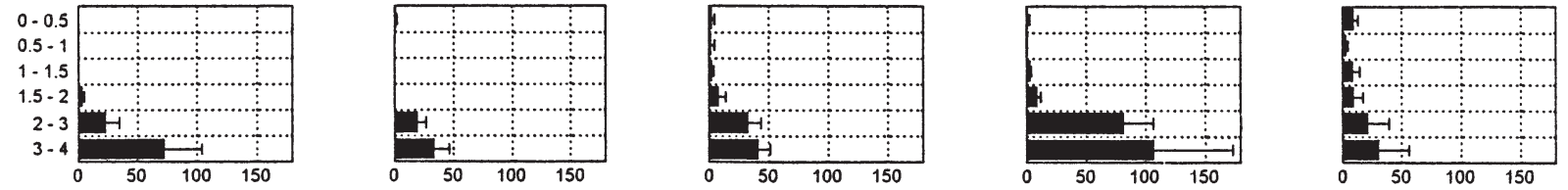

Fig. 3. (Above and facing page.) Depth distribution of the nematode species and the total nematode community for the 5 sampling events (horizontal axes: ind. $10 \mathrm{~cm}^{-2}$; vertical axes: depth in $\mathrm{cm}$ ) 
S1

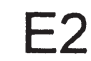

E3

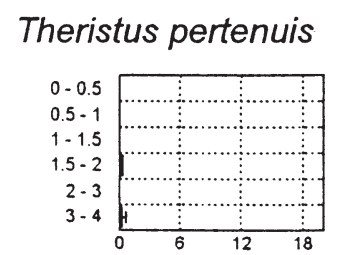

Viscosia viscosa
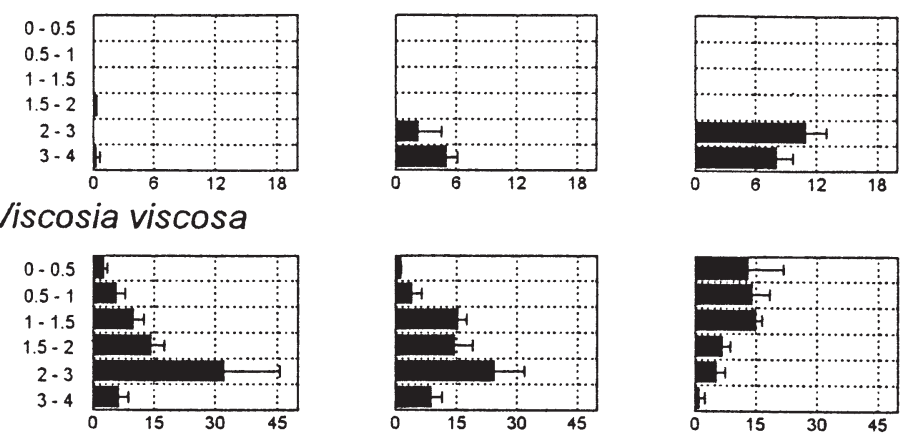

Total nematode community
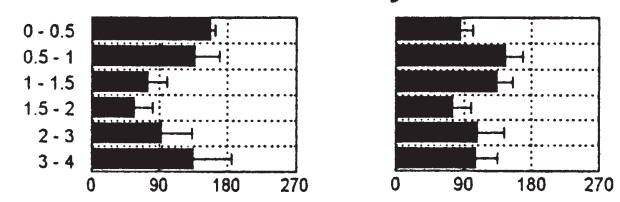
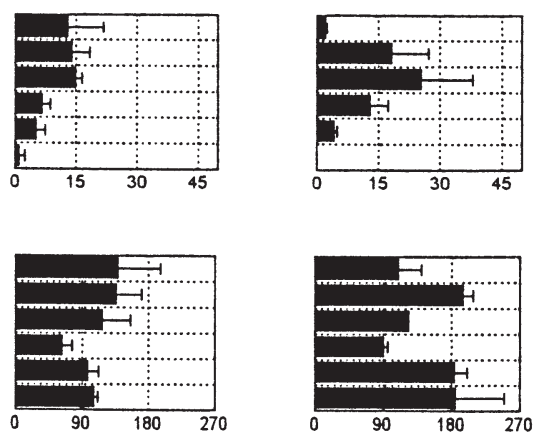

E4
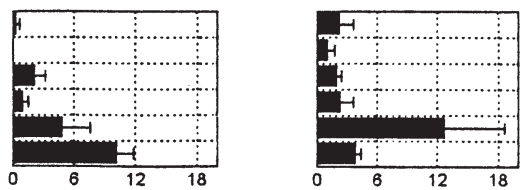

S5
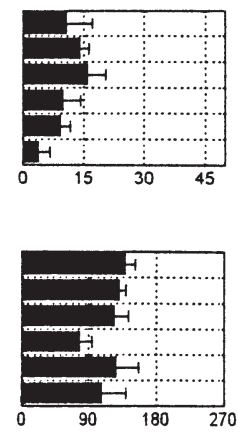

Fig. 3 (continued)

ing both flooding and ebbing when current velocities were highest. At the Molenplaat, current velocity peaks and extremely high loads of suspended particulate matter (500 $\mathrm{mg} \mathrm{l}^{-1}$ ) occur ca $1 \mathrm{~h}$ just before and after high tide, thus indicating strong hydrodynamics during these periods (Fig. 2). Hence, it is expected that the strongest downward migrations would occur on either side of high tide. This study partly confirms this hypothesis; Daptonema normandicum, D. setosum, Enoploides longispiculosus, Hypodontolaimus trichophora, and total nematodes were obviously less concentrated in top sediment layers just before high tide (S5), compared to the former measured submersion event (S1). Nevertheless, avoidance of erosion and resuspension cannot serve to explain the downward migration during exposure and subsequent re-entering of the more superficial layers during submersion, as observed for E. longispiculosus, D. normandicum (this study) and D. leviculum (Rieger \& Ott 1971). The upper submerged sediment layers may be more favourable (S1) only when current velocities are below the critical threshold of erosion $\left(0.23 \mathrm{~m} \mathrm{~s}^{-1}\right.$ at this site; J.W. pers. comm.).

Intertidal areas are subject to cyclic changes of the groundwater level, which is not more than $2 \mathrm{~cm}$ below the surface for intertidal flats of the Westerschelde (Oenema et al. 1988). This will have important implications for highly mobile nematodes such as Enoploides longispiculosus, which need to actively catch their prey. It may in part explain the migration of $E$. longispiculosus to deeper sediment layers during exposure. E. longispiculosus is a voracious predator of nematodes and oligochaetes and is probably prey-limited in the upper stratum of the sediment of this study site (Moens et al. 2000). Its presence near the sediment surface during submersion may also enable it to exploit additional sources of prey, e.g. temporary and permanent meiofauna transported through the water column. A recent study indicates that E. longispiculosus also forages on protozoan prey (I. Hamels et al. pers. comm.), which are abundant at the studied site (I. Hamels pers. comm.) and may migrate upward during submersion (Fegley 1987). Additionally, the downward migration during submersion and upward movement during exposure of Daptonema setosum may be associated with tidal migrations of its food source, epipelic diatoms (Hopkins 1963, Joint et al. 1982, Pinckney et al. 1994).

Forster (1998) demonstrated that estuarine nematodes can tolerate significant changes in salinity, an ability which is highly species-specific and related to the nematodes' distribution in the littoral. Compared to the rainfall-induced salinity changes in this study, the salinity increases observed on the Molenplaat during exposure (and in bright summer weather) were minor (from 24 PSU $1 \mathrm{~h}$ after emersion to a maximum of 28.5 PSU just prior to inundation) and unlikely to have provoked the vertical migration of nematodes at this site.

Temperature, however, increased significantly during low tide exposure, reaching maximal values at the sediment surface. The temperature values which ex- 
ceeded optima and perhaps even upper tolerance limits of many free-living aquatic nematode species (Heip et al. 1985, Moens \& Vincx 2000a, and references therein). In between optimal and upper lethal temperatures, even subtle temperature changes can impact reproductive and/or metabolic activity (Heip et al. 1985, Moens \& Vincx 2000a,b). Hence, the recorded temperature differences between sediment surface and subsurface layers may provide a significant stimulus for vertical migration, although this stimulus is probably only episodically important during sunny spring and summer weather.

The design of the present study does not allow us to identify the causes of the observed migrations, nor to assess their generality. It does, however, suggest hypotheses about flow, groundwater and temperature to be tested in the future. It also clearly demonstrates the necessity of a species-level approach for accurate assessment of tidal migrations of meiofauna.

Acknowledgements. This is a contribution (number 233) to the ELOISE Programme in the framework of the ECOFLAT project carried out under contract ENV4-CT96-0216 (EU programme Environment and Climate); and publication number 2818 from the Netherlands Institute of Ecology, Yerseke. The research was supported by Ghent University via contract BOF98-03. T.M. is a postdoctoral fellow with the Fund for Scientific Research-Flanders (F.W.O.). Johan Van de Velde, Annick Van Kenhove and Steven Degraer are acknowledged for their assistance during sampling and sample processing, and the crew of the RV 'Luctor' for transport to and from the Molenplaat. Ms B. J. Schimmelpennink (Rijkswaterstaat Direktie Zeeland, Meetnet ZEGE) is acknowledged for the water temperature data. We thank Jan Vanaverbeke, Ann Vanreusel and 2 anonymous referees for critically reading and commenting on an earlier version of this manuscript.

\section{LITERATURE CITED}

Boaden PJS, Platt HM (1971) Daily migration patterns in an intertidal meiobenthic community. Thalassia Jugos $7: 1-12$

Fegley SR (1987) Experimental variation of near-bottom current speeds and its effects on depth distribution of sandliving meiofauna. Mar Biol 95:183-191

Forster SJ (1998) Osmotic stress tolerance and osmoregulation of intertidal and subtidal nematodes. J Exp Mar Biol Ecol 224:109-125

Editorial responsibility: Lisa Levin (Contributing Editor), La Jolla, California, USA
Heip C, Vincx M, Vranken G (1985) The ecology of marine nematodes. Oceanogr Mar Biol Annu Rev 23:399-489

Herman PMJ, Middelburg JJ, Widdows J, Lucas CH, Heip CHR (2000) Stable isotopes as trophic tracers: combining field sampling and manipulative labelling of food resources for macrobenthos. Mar Ecol Prog Ser 204:79-92

Hopkins JT (1963) A study of the diatoms of the Ouse estuary, Sussex. I. The movement of the mud-flat diatoms in response to some chemical and physical changes. J Mar Biol Assoc UK 43:653-663

Joint IR, Gee JM, Warwick RM (1982) Determination of finescale vertical distribution of microbes and meiofauna in an intertidal sediment. Mar Biol 72:157-164

Middelburg JJ, Barranguet C, Boschker HTS, Herman PMJ, Moens T, Heip CHR (2000) The fate of intertidal microphytobenthos carbon: an in situ ${ }^{13} \mathrm{C}$ labelling study. Limnol Oceanogr 45:1224-1234

Moens T, Vincx M (2000a) Temperature and salinity constraints on the life cycle of two brackish-water nematode species. J Exp Mar Biol Ecol 243:115-135

Moens T, Vincx M (2000b) Temperature, salinity and food thresholds in two brackish-water bacterivorous nematode species: assessing niches from food absorption and respiration experiments. J Exp Mar Biol Ecol 243:137-154

Moens T, Herman PMJ, Verbeeck L, Steyaert M, Vincx M (2000) Predation rates and prey selectivity of two predacious marine nematode species. Mar Ecol Prog Ser 205: 185-193

Oenema O, Stekener R, Reynders J (1988) The soil environment of the intertidal area in the Westerschelde. Hydrobiol Bull 22:21-30

Palmer MA (1986) Hydrodynamics and structure: interactive effects on meiofauna dispersal. J Exp Mar Biol Ecol 104: 53-68

Palmer MA (1988) Dispersal of marine meiofauna: a review and conceptual model explaining passive transport and active emergence with implications for recruitment. Mar Ecol Prog Ser 48:81-91

Palmer MA, Gust G (1985) Dispersal of meiofauna in a turbulent tidal creek. J Mar Res 43:179-210

Pinckney J, Piceno Y, Lovell CR (1994) Short-term changes in the vertical distribution of benthic microalgal biomass in intertidal muddy sediments. Diatom Res 9:143-153

Renaud-Debyser J, Salvat B (1963) Eléments de prosperité des biotopes des sédiments meubles intertidaux et écologie de leurs populations en microfaune et macrofaune. Vie Milieu 14:463-550

Rieger R, Ott J (1971) Gezeitenbedingte Wanderungen von Turbellarien und Nematoden eines Nordadriatischen Sandstrandes. Vie Milieu 22(Suppl I):425-447

Steyaert M, Garner N, Van Gansbeke D, Vincx M (1999) Nematode communities from the North Sea: environmental controls on species diversity and vertical distribution within the sediment. J Mar Biol Assoc UK 79:253-264

Submitted: September 22, 2000; Accepted: August 13, 2001

Proofs received from author(s): November 8, 2001 